\title{
Simple Reduction of Hydantoins with Sodium Borohydride
}

\author{
Jun-Ichi Yamaguchi*, Emiko Shibuta, Yoshie Oishi \\ Department of Applied Chemistry, Kanagawa Institute of Technology, Atsugi, Japan \\ Email: yamagu@chem.kanagawa-it.ac.jp
}

Received 27 September 2014; revised 13 November 2014; accepted 30 November 2014

Copyright (C) 2014 by authors and Scientific Research Publishing Inc.

This work is licensed under the Creative Commons Attribution International License (CC BY). http://creativecommons.org/licenses/by/4.0/

c) (†) Open Access

\begin{abstract}
The reduction of various hydantoins with sodium borohydride gave the corresponding 4-hydroxy2-imidazolidinones in high yields. In contrast, reduction employing a boron trifluoride etheratesodium borohydride system generated 2 -imidazolidinones. In both reductions, the reactivity of the hydantoin was dependent on its substituents. The Lewis acid-promoted reactions of a 4-hydroxy-2-imidazolidinone with nucleophiles were also investigated.
\end{abstract}

\section{Keywords}

Hydantoin, Reduction, Imidazolidinone

\section{Introduction}

The hydantoins, five-membered heterocycles containing two nitrogen atoms, have a structural resemblance to 2-imidazolidinones and 2-oxazolidinones (Figure 1), both of which are known to act as chiral auxiliaries [1]. However, few studies of these compounds have been reported, with the exception of their utilization as precursors for natural products such as (+)-biotin (vitamin $H$ ) [2] [3].

Hydantoin and its derivatives may be useful as important precursors for bioactive compounds, and thus additional information concerning the reactivity of the hydantoins is still required. Herein, we report the reduction of hydantoins (1) with sodium borohydride, both with and without boron trifluoride etherate, resulting in the formation of 4-hydroxy-2-imidazolidinones (2) and 2-imidazolidinones (3), respectively, in high yields (Scheme 1). The first reported reduction of a hydantoin was the reaction of a 5-monosubstituted hydantoin with lithium aluminum hydride (LAH) in diethyl ether under reflux or using Red-Al ${ }^{\circledR}$, which generated $\mathbf{4}$ rather than 2 except when employing a 5,5-disubstituted hydantoin [4] [5], in which case 4-hydroxy-2-imidazolidinone was obtained since dehydration could not proceed [6] [7]. Reduction of 5-monosubstituted hydantoins with LAH or diisobu-

${ }^{*}$ Corresponding author. 


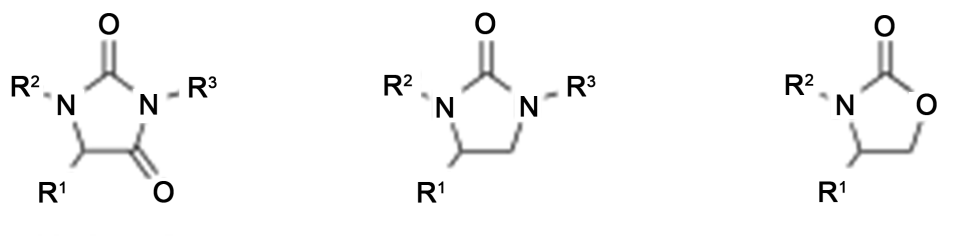

Hydantoin

2-Imidazolidinone

2-Oxazolidinone

Figure 1. Five-membered heterocycles containing nitrogen atoms.<smiles>[R]C1[C@H](O)N([R])C(=O)N1[R]</smiles>

2

$\mathrm{A}: \mathrm{R}^{1}=\mathrm{PhCH}_{2}-; \mathrm{B}: \mathrm{R}^{1}=j-\mathrm{Pr}$

C: $R^{1}=t-B_{O O C H}-; D: R^{1}=P_{2} H_{2} \mathrm{SCH}_{2}^{-}$

1
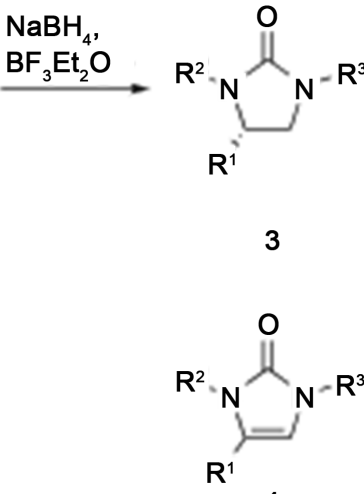

4

\section{Scheme 1. Reactions applied in the present work.}

tylaluminum hydride (DIBAL) below room temperature also resulted in the formation of 4 rather than 2 [8]-[10]. Only one example of the reduction of a 1-alkylhydantoin has been described, in which a compound derived from cysteine was reduced using sodium borohydride by Chavan and co-workers in the synthesis of biotin [3].

\section{Results and Discussion}

Initial trials involved the treatment of $\mathbf{1}$ with excess amounts of sodium borohydride in methanol at room temperature, with the results shown in Table $\mathbf{1}$. The reactivity of $\mathbf{1}$ and the yield of $\mathbf{2}$ were evidently dependent on the substituents of $\mathbf{1}$. In cases in which $\mathbf{1}$ was derived from phenylalanine, the reduction of $\mathbf{1}$ bearing a phenyl group at the 3-position proceeded, generating 2 in high yield (Entry 1). However, when the substituent at the 3position was changed to a phenethyl group, the reduction rate was very slow and only a low yield of 2-imidazolone (4), formed by dehydration of $\mathbf{2}$, was obtained (Entry 2). We suspected that the lack of a substituent at the 1-position of $\mathbf{1}$ (that is, $\mathrm{R}^{2}=\mathrm{H}$ ) decreased its reactivity, and so the $t$-butoxycarbonyl (Boc) derivative of $\mathbf{1}$ was prepared by $t$-butoxycarbonylation with $\mathrm{Boc}_{2} \mathrm{O}$. During reduction of the Boc derivative, the dehydration of 2 was suppressed and thus the yield of $\mathbf{2}$ was dramatically improved (Entry 3). The reduction of other hydantoins derived from various amino acid amides gave similar results. Based on the above results, the Boc group at the 1-position of the hydantoin ring was effective in promoting the present reduction (Entries 4-9).

Following the initial trials, the Lewis acid-promoted reactions of $\mathbf{2}$ with an allylsilane or an enol silyl ether to give the coupling products 5 were assessed, with the results presented in Table 2 . The reaction of $\mathbf{2}$ with the allylsilane at $0^{\circ} \mathrm{C}$ resulted in the formation of $\mathbf{5 - H}$ as a single isomer via the removal of the Boc group, with some 4 generated as a by-product (Entry 1$)$. When the reaction was performed at a lower temperature $\left(-78^{\circ} \mathrm{C}\right)$, the yield of $\mathbf{5}$ was increased and formation of $\mathbf{4}$ was suppressed (Entry 2). In contrast, when using the enol silyl ether as the nucleophile, the reaction gave better results at $0^{\circ} \mathrm{C}$ than at $-78^{\circ} \mathrm{C}$ and the resulting products, 5-Boc and 5-H, were produced as single isomers (Entries 3 and 4). Chavan and co-workers have reported a similar reaction system using 4-hydroxy-2-imidazolidinones, in which the products exhibit exclusively trans stereochemistry. Although experimental and spectral data regarding the stereochemistries of 5-Boc and 5-H were not obtained in this study, based on the similarity of the present reaction system to that reported by Chavan, as well as the structure of intermediate $\mathbf{6}$, we believe that the stereochemistries of both compounds were likely trans in the case of the present reactions. 
Table 1. Reduction of $\mathbf{1}$ with sodium borohydride to 2 .

\begin{tabular}{|c|c|c|c|c|c|c|}
\hline \multirow[t]{2}{*}{ Entry } & \multirow[t]{2}{*}{$\mathrm{R}^{1}$} & \multirow[t]{2}{*}{$\mathrm{R}^{2}$} & \multirow[t]{2}{*}{$\mathrm{R}^{3}$} & \multirow[t]{2}{*}{ Time/h } & \multicolumn{2}{|c|}{ Yield/\% } \\
\hline & & & & & 2 & 4 \\
\hline 1 & A & $\mathrm{H}$ & $\mathrm{Ph}$ & 1 & 77 & \\
\hline 2 & A & $\mathrm{H}$ & $\mathrm{Ph}\left(\mathrm{CH}_{2}\right)_{2}$ & 2.5 & 0 & 14 \\
\hline 3 & A & Boc $^{a}$ & $\mathrm{Ph}\left(\mathrm{CH}_{2}\right)_{2}$ & 0.5 & 97 & \\
\hline 4 & B & $\mathrm{H}$ & $\mathrm{Ph}\left(\mathrm{CH}_{2}\right)_{2}$ & 0.5 & & $\mathrm{NI}^{\mathrm{b}}$ \\
\hline 5 & B & Boc & $\mathrm{Ph}\left(\mathrm{CH}_{2}\right)_{2}$ & 0.5 & 79 & \\
\hline 6 & $\mathrm{C}$ & $\mathrm{H}$ & $\mathrm{Ph}\left(\mathrm{CH}_{2}\right)_{2}$ & 0.5 & & NI \\
\hline 7 & $\mathrm{C}$ & Вос & $\mathrm{Ph}\left(\mathrm{CH}_{2}\right)_{2}$ & 0.5 & 94 & \\
\hline 8 & $\mathrm{D}$ & $\mathrm{H}$ & $\mathrm{Ph}$ & 0.5 & 35 & \\
\hline 9 & $\mathrm{D}$ & Boc & $\mathrm{Ph}$ & 1 & 87 & \\
\hline
\end{tabular}

${ }^{\mathrm{a}} \mathrm{t}$-Butoxycarbonyl. ${ }^{\mathrm{b}}$ Neither $\mathbf{2}$ nor $\mathbf{4}$ were isolated.

Table 2. Lewis acid-promoted reaction of $\mathbf{2}$ with nucleophiles.

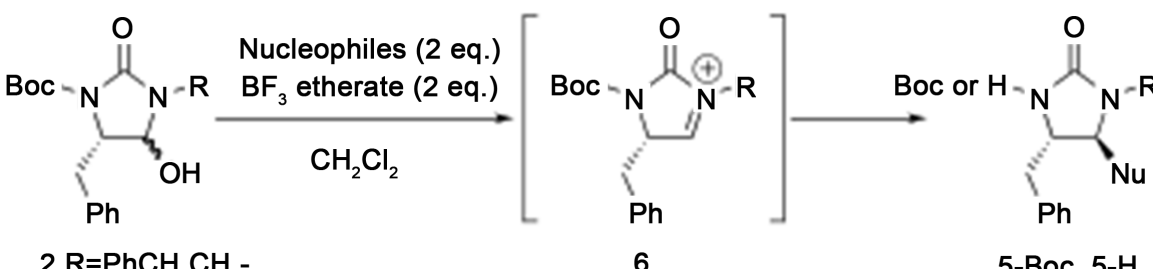

$2 \mathrm{R}=\mathrm{PhCH}_{2} \mathrm{CH}_{2}-$

6

5-Boc, 5-H

\begin{tabular}{|c|c|c|c|c|c|}
\hline \multirow[t]{2}{*}{ Entry } & \multirow[t]{2}{*}{$\mathrm{Nu}$} & \multirow[t]{2}{*}{ Conditions } & \multicolumn{3}{|c|}{ Yield/\% } \\
\hline & & & 5-Boc & 5-H & 4 \\
\hline 1 & A & $0^{\circ} \mathrm{C}-\mathrm{RT}, \mathrm{ON}$ & & 58 & 38 \\
\hline 2 & A & $-78^{\circ} \mathrm{C}, \mathrm{ON}$ & 27 & 60 & \\
\hline 3 & B & $0^{\circ} \mathrm{C}, 1.5 \mathrm{~h}$ & & 97 & \\
\hline 4 & B & $-78^{\circ} \mathrm{C}, 2 \mathrm{~h}$ & 24 & 9 & 15 \\
\hline
\end{tabular}

ON = overnight.

Although the chiral compounds 2-imidazolidinone (3) and 2-oxazolidinone are both well known as chiral auxiliaries [11]-[15], few methods for the preparation of $\mathbf{3}$ have been reported [16]-[18]. We expected that $\mathbf{1}$ would be converted to $\mathbf{3}$ when using a relatively strong reducing agent. Among the many possible reduction methods, a candidate for the conversion to 3 was a sodium borohydride-boron trifluoride etherate system, typically employed to transform amino acids to amino alcohols [19]. When using the hydantoins derived from phenylalanine, the reduction proceeded at room temperature to generate 3 in high yields (Table 3, Entries 1-3). Conversely, the reduction of $1\left(R^{1}=A, R^{2}=H, R^{3}=P h\right)$ using 4.0 equimolar amounts of a commercial borane-tetrahydrofuran complex gave the corresponding version of $\mathbf{3}$ in $43 \%$ yield, meaning that the present reduction system represents a useful means of preparing many different 2-imidazolidinones. With regard to the present reduction, it was determined that the reactivity of $\mathbf{1}$ bearing an isopropyl group at the 5-position was affected by the substituent at the 1-position. The conversion of $\mathbf{1}$ bearing a Boc group to $\mathbf{3}$ proceeded successfully and generated high yields, with removal of the Boc group (Entry 6). We believe that the carbamic acid-like species $\mathbf{7}$ or $\mathbf{8}$, which is more reactive than $\mathbf{1}\left(\mathrm{R}^{2}=\mathrm{H}\right)$, might be generated in the reaction mixture, and that $\mathbf{3}$ is ob- 
Table 3. Reduction of $\mathbf{1}$ to $\mathbf{3}$ in the sodium borohydride-boron trifluoride etherate system.
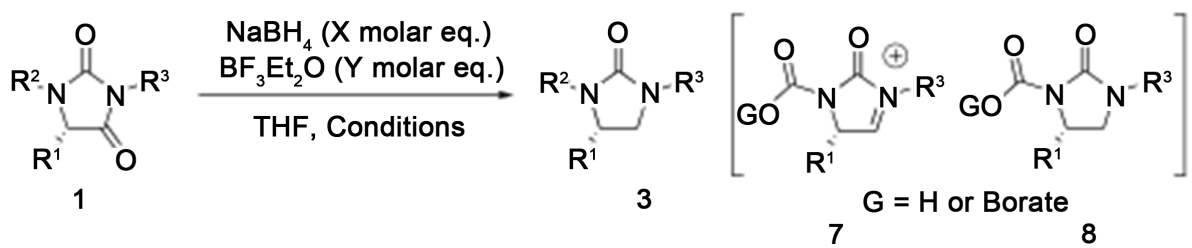

\begin{tabular}{|c|c|c|c|c|c|c|c|}
\hline Entry & $\mathrm{R}^{1}$ & $\mathrm{R}^{2}$ & $\mathrm{R}^{3}$ & $\mathrm{X}$ & $\mathrm{Y}$ & Conditions & Yield \\
\hline & & & & leq. & leq. & $/ \%$ & \\
\hline 1 & A & $\mathrm{H}$ & $\mathrm{Ph}$ & 4 & 2 & RT, 3 h & 96 \\
\hline 2 & A & $\mathrm{H}$ & $\mathrm{Ph}\left(\mathrm{CH}_{2}\right)_{2}$ & 4 & 2 & $\mathrm{RT}, 4.5 \mathrm{~h}$ & 83 \\
\hline 3 & A & $\mathrm{H}$ & $\mathrm{Bu}^{t}$ & 4 & 2 & $\mathrm{RT}, 22 \mathrm{~h}$ & 81 \\
\hline 4 & B & $\mathrm{H}$ & $\mathrm{Ph}$ & 4 & 2 & reflux, $4 \mathrm{~h}$ & 62 \\
\hline 5 & B & $\mathrm{H}$ & $\mathrm{Ph}\left(\mathrm{CH}_{2}\right)_{2}$ & 4 & 2 & reflux, $3 \mathrm{~h}$ & 29 \\
\hline 6 & B & Boc & $\mathrm{Ph}\left(\mathrm{CH}_{2}\right)_{2}$ & 4 & 4 & reflux, $5 \mathrm{~h}$ & $71^{\mathrm{a}}$ \\
\hline 7 & $\mathrm{C}$ & $\mathrm{H}$ & $\mathrm{Ph}$ & 4 & 2 & reflux, 2 h & $61^{\mathrm{b}}$ \\
\hline 8 & $\mathrm{C}$ & $\mathrm{H}$ & $\mathrm{Ph}\left(\mathrm{CH}_{2}\right)_{2}$ & 4 & 2 & reflux, 2 h & $62^{\mathrm{b}}$ \\
\hline 9 & $\mathrm{D}$ & $\mathrm{H}$ & $\mathrm{Ph}$ & 4 & 2 & reflux, $3 \mathrm{~h}$ & 78 \\
\hline
\end{tabular}

${ }^{\mathrm{a}}$ The Boc group was removed. ${ }^{\mathrm{b}}$ No removal of the $t$-butyl group occurred.

tained as the final product after a formation of iminium salt 7 and decarboxylation of $\mathbf{8}$. The reductions of other hydantoins without a Boc group proceeded, forming the corresponding 3 compounds (Entries 7-9). It was also observed that the $t$-butyl ether bond was stable under these reaction conditions (Entries 7 and 8).

\section{Conclusion}

In conclusion, the reduction of hydantoins with sodium borohydride in the absence or presence of boron trifluoride etherate gave 4-hydroxy-2-imidazolidinones or 2-imidazolidinones, respectively. Additional novel methods for achieving the conversions of compounds $\mathbf{2}$ and $\mathbf{3}$ are now being studied.

\section{Spectral Data}

4-benzyl-5-hydroxy-1-phenyl-1,3-imidazolidine-2-one: the mixture of diastereomers, Entry 1 in Table 1.

${ }^{1} \mathrm{H}$ NMR $\left(300 \mathrm{MHz}, \mathrm{CDCl}_{3}\right) \delta=2.62(1 \mathrm{H}, \mathrm{s}), 2.75-2.90(2 \mathrm{H}, \mathrm{m}), 3.35-385(1 \mathrm{H}, \mathrm{m}), 4.00-4.10(1 \mathrm{H}, \mathrm{m})$, $6.95-7.60(10 \mathrm{H}, \mathrm{m})$.

4-benzyl-5-hydroxy-1-phenethyl-1,3-imidazolidine-2-one: the mixture of diastereomers, Entry 3 in Table 1.

${ }^{1} \mathrm{H}$ NMR (300 MHz, $\left.\mathrm{CDCl}_{3}\right) \delta=1.54(9 \mathrm{H}, \mathrm{s}), 2.75$ - $2.85(2 \mathrm{H}, \mathrm{m}), 3.15$ - 3.65 (4H, m), $4.05-4.20(2 \mathrm{H}, \mathrm{m})$, 4.75 - $4.85(1 \mathrm{H}, \mathrm{m}), 7.10-7.40(5 \mathrm{H}, \mathrm{m})$.

5-hydroxy-4-isopropyl-1-phenethyl-1,3-imidazolidine-2-one: the mixture of diastereomers, Entry 5 in Table 1.

${ }^{1} \mathrm{H}$ NMR (300 MHz, $\left.\mathrm{CDCl}_{3}\right) \delta=0.65,0.95,1.00$, and1.02 (6H, 4d, $\left.\mathrm{J}=7.1 \mathrm{~Hz}\right), 1.50$ and 1.51 (9H, 2s), 2.15 and $2.42(1 \mathrm{H}, 2$ octet, $\mathrm{J}=7.1 \mathrm{~Hz}), 2.85-3.00(2 \mathrm{H}, \mathrm{m}), 3.40-4.70(3 \mathrm{H}, \mathrm{m}), 4.73$ and $5.15(1 \mathrm{H}, \mathrm{d}$ and t, $\mathrm{J}=7.1$ $\mathrm{Hz}), 7.15-7.30(5 \mathrm{H}, \mathrm{m})$.

3-tert-butoxycarbonyl-4-tert-butoxymethyl-5-hydroxy-1-phenethyl-1,3-imidazolidine-2-one: the mixture of diastereomers, Entry 7 in Table 1.

${ }^{1} \mathrm{H}$ NMR (300 MHz, CDCl $) \delta=1.16(9 \mathrm{H}, \mathrm{s}), 1.53(9 \mathrm{H}, \mathrm{s}), 2.75-3.00(2 \mathrm{H}, \mathrm{m}), 3.45-3.55(2 \mathrm{H}, \mathrm{m}), 3.70$ $3.80(1 \mathrm{H}, \mathrm{m}), 4.05$ - $4.15(2 \mathrm{H}, \mathrm{m}), 4.60$ - $4.66(1 \mathrm{H}, \mathrm{m}), 5.00$ - $5.10(1 \mathrm{H}, \mathrm{m}), 7.15$ - $7.35(5 \mathrm{H}, \mathrm{m})$.

4-benzylthiomethyl-5-hydroxy-1-phenyl-1,3-imidazolidine-2-one: the mixture of diastereomers, Entry 8 in Table 1.

${ }^{1} \mathrm{H}$ NMR $\left(300 \mathrm{MHz}, \mathrm{CDCl}_{3}\right) \delta=2.75-3.10(2 \mathrm{H}, \mathrm{m}), 3.60-3.80$ and $4.20-4.40(2 \mathrm{H}, \mathrm{m}), 4.70-4.80(2 \mathrm{H}, \mathrm{m})$ $7.05-7.60(10 \mathrm{H}, \mathrm{m})$.

3-tert-butoxycarbonyl-4-benzylthiomethyl-5-hydroxy-1-phenethyl-1,3-imidazolidine-2-one: the mixture of 
diastereomers, Entry 9 in Table 1.

${ }^{1} \mathrm{H}$ NMR (300 MHz, $\left.\mathrm{CDCl}_{3}\right) \delta=1.50$ and $1.51(9 \mathrm{H}, 2 \mathrm{~s}), 2.50-2.60(1 \mathrm{H}, \mathrm{m}), 2.90-3.00(1 \mathrm{H}, \mathrm{m}), 3.80$ and

3.85 (2H, 2s), 4.05 - 4.10 (1H, m), 5.16 - 5.25 (1H, m), 7.15 - $7.70(10 \mathrm{H}, \mathrm{m})$.

4-benzyl-5-phenacyl-1-phenethyl-1,3-imidazolidine-2-one: 5-H, Entries 1 and 2 in Table 2.

${ }^{1} \mathrm{H}$ NMR (300 MHz, CDCl $) \delta=2.50$ - 2.55 (1H, m), 2.75 - 3.15 (6H, m), 3.15 - $3.30(1 \mathrm{H}, \mathrm{m}), 3.40$ - $3.45(1 \mathrm{H}$, m), 3.75 - $3.80(1 \mathrm{H}, \mathrm{m}), 3.95-4.00(1 \mathrm{H}, \mathrm{m}), 4.44$ (1H, brs), $6.95-7.35(10 \mathrm{H}, \mathrm{m}), 7.48(2 \mathrm{H}, \mathrm{t}, \mathrm{J}=6.6 \mathrm{~Hz}), 7.58$ $(1 \mathrm{H}, \mathrm{t}, \mathrm{J}=6.6 \mathrm{~Hz}), 7.88(2 \mathrm{H}, \mathrm{d}, \mathrm{J}=6.6 \mathrm{~Hz})$.

4-benzyl-3-tert-butoxycarbonyl-5-phenacyl-1-phenethyl-1,3-imidazolidine-2-one: 5-Boc, Entry 2 in Table 2.

${ }^{1} \mathrm{H}$ NMR (300 MHz, $\left.\mathrm{CDCl}_{3}\right) \delta=1.56(9 \mathrm{H}, \mathrm{s}), 2.45-2.55(2 \mathrm{H}, \mathrm{m}), 2.80-3.10(5 \mathrm{H}, \mathrm{m}), 3.65-3.90$ (2H, m), $4.00-4.05$ (1H, m), $7.05-7.35(1 \mathrm{H}, \mathrm{m}), 7.45(2 \mathrm{H}, \mathrm{t}, \mathrm{J}=7.8 \mathrm{~Hz}), 7.56(1 \mathrm{H}, \mathrm{t}, \mathrm{J}=7.8 \mathrm{~Hz}), 7.78(2 \mathrm{H}, \mathrm{d}, \mathrm{J}=7.8$ $\mathrm{Hz})$.

5-allyl-4-benzyl-1-phenethyl-1,3-imidazolidine-2-one: 5-H, Entries 3 and 4 in Table 2.

${ }^{1} \mathrm{H}$ NMR $\left(300 \mathrm{MHz}, \mathrm{CDCl}_{3}\right) \delta=2.22(2 \mathrm{H}, \mathrm{t}, \mathrm{J}=5.9 \mathrm{~Hz}), 2.53(1 \mathrm{H}, \mathrm{dd}, \mathrm{J}=13.4$ and $8.3 \mathrm{~Hz}), 2.63(1 \mathrm{H}, \mathrm{dd}, \mathrm{J}=$ 13.4 and $5.6 \mathrm{~Hz}), 3.05-3.30(2 \mathrm{H}, \mathrm{m}), 3.48(1 \mathrm{H}, \mathrm{dt}, \mathrm{J}=7.2$ and $5.9 \mathrm{~Hz}), 3.79(1 \mathrm{H}, \mathrm{ddd}, \mathrm{J}=8.3,7.2$, and $5.6 \mathrm{~Hz})$, 4.53 (1H, brs), 5.00 - $5.10(2 \mathrm{H}, \mathrm{m}), 5.50$ - $5.65(1 \mathrm{H}, \mathrm{m}), 7.05-7.40(10 \mathrm{H}, \mathrm{m})$.

5-allyl-4-benzyl-3-tert-butoxycarbonyl-1-phenethyl-1,3-imidazolidine-2-one: 5-Boc, Entry 4 in Table 2.

${ }^{1} \mathrm{H}$ NMR (300 MHz, $\left.\mathrm{CDCl}_{3}\right) \delta=1.58(9 \mathrm{H}, \mathrm{s}), 2.00-2.10(2 \mathrm{H}, \mathrm{m}), 2.30-2.45(1 \mathrm{H}, \mathrm{m}), 2.70-2.90(2 \mathrm{H}, \mathrm{m})$, 3.00 - 3.15 (3H, m), 3.84 - 4.00 (2H, m), 4.90 - 5.00 (2H, m), 5.15 - 5.30 (1H, m), 6.96 (d, J = 6.6 Hz), 7.15 -

$7.40(8 \mathrm{H}, \mathrm{m})$.

4-benzyl-1-phenyl-1,3-imidazolidine-2-one: Entry 1 in Table 3.

${ }^{1} \mathrm{H}$ NMR (300 MHz, $\left.\mathrm{CDCl}_{3}\right) \delta=2.80-2.95$ (2H, m), 3.60 - 3.70 (1H, m), 3.95 - 4.05 (2H, m), $4.95(1 \mathrm{H}, \mathrm{s})$,

$7.05(1 \mathrm{H}, \mathrm{t}, \mathrm{J}=7.6 \mathrm{~Hz}), 7.20-7.40(7 \mathrm{H}, \mathrm{m}), 7.53(2 \mathrm{H}, \mathrm{d}, \mathrm{J}=7.6 \mathrm{~Hz})$.

4-benzyl-1-phenethyl-1,3-imidazolidine-2-one: Entry 2 in Table 3.

${ }^{1} \mathrm{H}$ NMR (300 MHz, $\left.\mathrm{CDCl}_{3}\right) \delta=2.65-2.80(2 \mathrm{H}, \mathrm{m}), 2.80(2 \mathrm{H}, \mathrm{t}, \mathrm{J}=7.6 \mathrm{~Hz}), 3.02(1 \mathrm{H}$, dd, $\mathrm{J}=8.6$ and 5.6

$\mathrm{Hz}), 3.25$ - 3.50 (3H, m), 3.79 (1H, quint, J = 6.8 Hz), $4.96(1 \mathrm{H}, \mathrm{s}), 7.05-7.35$ (10H, m).

4-benzyl-1-tert-butyl-1,3-imidazolidine-2-one: Entry 3 in Table 3.

${ }^{1} \mathrm{H}$ NMR (300 MHz, $\left.\mathrm{CDCl}_{3}\right) \delta=1.34(9 \mathrm{H}, \mathrm{s}), 2.75-2.85(2 \mathrm{H}, \mathrm{m}), 3.16(1 \mathrm{H}, \mathrm{dd}, \mathrm{J}=8.6 \mathrm{and} 6.1 \mathrm{~Hz}), 3.50(1 \mathrm{H}$, t, J = 8.3 Hz), 3.70 - 3.80 (1H, m), 4.46 (1H, s), 7.15 - 7.35 (5H, m).

4-isopropyl-1-phenyl-1,3-imidazolidine-2-one: Entry 4 in Table 3.

${ }^{1} \mathrm{H}$ NMR (300 MHz, CDCl $) \delta=0.96$ (3H, d, J = 6.9 Hz), 0.99 (3H, d, J=6.9 Hz), $1.74(1 \mathrm{H}$, Octet, J = 6.9 Hz), 3.45 - 3.60 (2H, m), 3.85 - $4.00(1 \mathrm{H}, \mathrm{m}), 5.89(1 \mathrm{H}, \mathrm{s}), 7.03(1 \mathrm{H}, \mathrm{t}, \mathrm{J}=7.3 \mathrm{~Hz}), 7.33$ (2H, t, J = 7.3 Hz), 7.55 (2H, d, $\mathrm{J}=7.3 \mathrm{~Hz})$.

4-isopropyl-1-phenethyl-1,3-imidazolidine-2-one: Entries 5 and 6 in Table 3.

${ }^{1} \mathrm{H}$ NMR (300 MHz, $\left.\mathrm{CDCl}_{3}\right) \delta=0.75(3 \mathrm{H}, \mathrm{d}, \mathrm{J}=6.8 \mathrm{~Hz}), 0.86(3 \mathrm{H}, \mathrm{d}, \mathrm{J}=6.1 \mathrm{~Hz}), 1.95-2.05(1 \mathrm{H}, \mathrm{m}), 2.82$ $(2 \mathrm{H}, \mathrm{t}, \mathrm{J}=7.7 \mathrm{~Hz}), 2.91(1 \mathrm{H}, \mathrm{t}, \mathrm{J}=8.2 \mathrm{~Hz}), 3.13(1 \mathrm{H}, \mathrm{t}, \mathrm{J}=9.2 \mathrm{~Hz}), 3.25$ - $3.50(3 \mathrm{H}, \mathrm{m}), 7.15-7.35(6 \mathrm{H}, \mathrm{m})$. 4-tert-butoxymethyl-1-phenyl-1,3-imidazolidine-2-one: Entry 7 in Table 3.

${ }^{1} \mathrm{H}$ NMR (300 MHz, CDCl $) \delta=1.20(9 \mathrm{H}, \mathrm{s}), 3.39$ (2H, d, J = 8.8 Hz), $3.58(1 \mathrm{H}, \mathrm{dd}, \mathrm{J}=4.9$ and $9.0 \mathrm{~Hz}), 3.85$ $3.95(1 \mathrm{H}, \mathrm{m}), 4.00(1 \mathrm{H}, \mathrm{t}, \mathrm{J}=9.0 \mathrm{~Hz}), 5.34$ (1H, brs), $7.05(1 \mathrm{H}, \mathrm{t}, \mathrm{J}=9.0 \mathrm{~Hz}), 7.36$ (2H, t, J = 9.0 Hz), 7.55 (2H, $\mathrm{d}, \mathrm{J}=9.0 \mathrm{~Hz})$.

4-tert-butoxymethyl-1-phenethyl-1,3-imidazolidine-2-one: Entry 8 in Table 3.

${ }^{1} \mathrm{H}$ NMR (300 MHz, $\left.\mathrm{CDCl}_{3}\right) \delta=1.15(9 \mathrm{H}, \mathrm{s}), 2.84(2 \mathrm{H}, \mathrm{t}, \mathrm{J}=9.0 \mathrm{~Hz}), 2.96(1 \mathrm{H}, \mathrm{dd}, \mathrm{J}=9.0 \mathrm{and} 5.4 \mathrm{~Hz}), 3.18$

(2H, d, J = 10.8 Hz), 3.35-3.55 (3H, m), 3.60-3.75 (1H, m), 4.76 (1H, brs), 7.15-7.35 (5H, m).

4-benzylthiomethyl-1-phenyl-1,3-imidazolidine-2-one: Entry 9 in Table 3.

${ }^{1} \mathrm{H}$ NMR (300 MHz, CDCl $) \delta=2.61(2 \mathrm{H}, \mathrm{d}, \mathrm{J}=7.6 \mathrm{~Hz}), 3.55(1 \mathrm{H}, \mathrm{dd}, \mathrm{J}=10.1$ and $9.1 \mathrm{~Hz}), 3.76(2 \mathrm{H}, \mathrm{s})$, 3.70 - 3.80 (1H, m), $3.95(1 \mathrm{H}, \mathrm{t}, \mathrm{J}=9.0 \mathrm{~Hz}), 5.29$ (1H, brs), 7.03 (1H, t, J = 8.2 Hz), 7.10 - 7.35 (7H, m), 7.57 $(2 \mathrm{H}, \mathrm{d}, \mathrm{J}=8.2 \mathrm{~Hz})$.

\section{References}

[1] Yamaguchi, J., Harada, M., Narushima, T., Saitoh, A., Nozaki, K., and Suyama, T. (2005) Diastereoselective Conjugate Addition of 1-(a,b-Unsaturated acyl)hydantoin with Nucleophiles. Tetrahedron Letters, 46, 6411-6415. http://dx.doi.org/10.1016/j.tetlet.2005.07.116

[2] Chavan, S.P., Tejwani, R.B. and Ravindranathan, T. (2001) A Switch of Reactivity Profile in Ionic Intramolecular Annulation Reactions: A Short and Efficient Synthesis of D-(+)-Biotin. Journal of the Organic Chemistry, 66, 6197- 
6201. http://dx.doi.org/10.1021/jo015730j

[3] Chavan, S.P., Chittiboyina, A.G., Ravindranathan, T., Kamat, S.K. and Kalkote, U.R. (2005) Diastereoselective Amidoalkylation of $(3 S, 7 a R)-6-B e n z y l-7-h y d r o x y-3-p h e n y l t e t r a h y d r o-5 H-i m i a z o[1,5-c][1,3]$ thiazol-5-one: A Short and Highly Efficient Synthesis of (+)-Biotin. Journal of the Organic Chemistry, 70, 1901-1903. http://dx.doi.org/10.1021/jo0488107

[4] Wilk, I.J. and Close, W.J. (1950) The Action of Lithium Aluminum Hydride on 3-Methyl-5-phenylhydantoin and 5Phenylhydantoin. Journal of the Organic Chemistry, 15, 1020-1022. http://dx.doi.org/10.1021/jo01151a017

[5] Li, C.-D., Lee, M.H. and Sartorelli, A.C. (1979) Synthesis and Biological Evaluation of Tetramisole Analogues as Inhibitors of Alkaline Phosphatase of the 6-Thiopurine-Resistant Tumor Sarcoma 180/TG ${ }^{1}$. Journal of Medicinal Chemistry, 22, 1030-1033. http://dx.doi.org/10.1021/jm00195a003

[6] Marshall, F.J. (1956) Lithium Aluminum Hydride Reduction of Some Hydantoins, Barbiturates and Thiouracils. The Journal of American Chemical Society, 78, 3696-3697. http://dx.doi.org/10.1021/ja01596a038

[7] Cortes, S. and Kohn, H. (1983) Selective Reductions of 3-Substituted Hydantoins to 4-Hydroxy-2-imidazolidinones and Vicinal Diamines. Journal of the Organic Chemistry, 48, 2246-2254. http://dx.doi.org/10.1021/jo00161a021

[8] Cortes, S. and Kohn, H. (1983) Selective Reductions of 3-Substituted Hydantoins to 4-Hydroxy-2-imidazolidinones and Vicinal Diamines. Journal of the Organic Chemistry, 48, 2246-2254. http://dx.doi.org/10.1021/jo00161a021

[9] Liao, Z.-K. and Kohn, H. (1984) Synthesis of Substituted 2-Imidazolidinones and Annelated Hydantoin via Amidoalkylation Transformations. Journal of the Organic Chemistry, 49, 4745-4752. http://dx.doi.org/10.1021/jo00199a001

[10] Moolenaar, M.J., Speckamp, W.N., Hiemstra, H., Poetsch, E. and Casutt, M. (1995) Synthesis of D-(+)-Biotin through Selective Ring Closure of $N$-Acyliminium Silyl Enol Ether. Angewandte Chemie International Edition, 34, 2391-2393. http://dx.doi.org/10.1002/anie.199523911

[11] Drewes, S.E., Malissar, D.G.S. and Roos, G.H.P. (1993) Ephedrine-Derived Imidazolidin-2-Ones. Broad Utility Chiral Auxiliaries in Asymmetric Synthesis. Chemische Berichte, 126, 2663-2673. http://dx.doi.org/10.1002/cber.19931261216

[12] Taguchi, T., Shibuya, A., Sasaki, H., Endo, J., Morikawa, T. and Shiro, M. (1994) Asymmetric Synthesis of Difluorocyclopropanes. Tetrahedron: Asymmetry, 5, 1423-1426. http://dx.doi.org/10.1016/0957-4166(94)80101-0

[13] Bongini, A., Cardillo, G., Gentilucci, L. and Tomasini, C. (1997) Synthesis of Enantiomerically Pure Aziridine-2-Imides by Cyclization of Chiral 3'-Benzyloxyamino Imide Enolates. Journal of Organic Chemistry, 62, 9148-9153. http://dx.doi.org/10.1021/jo971254e

[14] Guillena, G. and Najera, C. (1998) PTC and Organic Bases-LiCl Assisted Alkylation of Imidazolidinone-Glycine Iminic Derivatives for the Asymmetric Synthesis of $\alpha$-Amino Acids. Tetrahedron: Asymmetry, 9, 3935-3938. http://dx.doi.org/10.1016/S0957-4166(98)00402-9

[15] Guillena, G. and Najera, C. (2000) 1,5-Dimethyl-4-Phenylimidazolidin-2-One-Derived Iminic Glycinimides: Useful New Reagents for Practical Asymmetric Synthesis of $\alpha$-Amino Acids. Journal of Organic Chemistry, 65, 7310-7322. http://dx.doi.org/10.1021/jo000321t

[16] Kim, T.H. and Lee, G.-J. (1999) Regiocontrolled Cyclization Reaction of $N$-(2-Hydroxy)Ureas by Transfer of Activation: One-Pot Synthesis of 2-Imidazolidinones. Journal of Organic Chemistry, 64, 2941-2943. http://dx.doi.org/10.1021/jo9820061

[17] Kim, T.H. and Lee, G.-J. (2000) L-Valinol and L-Phenylalaninol-Derived 2-Imidazolidinones as Chiral Auxiliaries in Asymmetric Aldol Reactions. Tetrahedron Letters, 41, 1505-1508. http://dx.doi.org/10.1016/S0040-4039(99)02325-4

[18] Nadir, U.K., Krishna, R.V. and Singh, A. (2005) A New and Facile Route for the Synthesis of Chiral 1,2-Diamines and 2,3-Diamino Acids. Tetrahedron Letters, 46, 479-482. http://dx.doi.org/10.1016/j.tetlet.2004.11.088

[19] Tschantz, M.A., Burgess, L.E. and Meyers, A.I. (1996) (S)-(-)-5-Heptyl-2-pyrrolidineone. Chiral Bicyclic Lactams as Templates for Pyrrolidines and Pyrrolidinones. Organic Synthesis, 73, 221-230. 
Scientific Research Publishing (SCIRP) is one of the largest Open Access journal publishers. It is currently publishing more than 200 open access, online, peer-reviewed journals covering a wide range of academic disciplines. SCIRP serves the worldwide academic communities and contributes to the progress and application of science with its publication.

Other selected journals from SCIRP are listed as below. Submit your manuscript to us via either submit@scirp.org or Online Submission Portal.
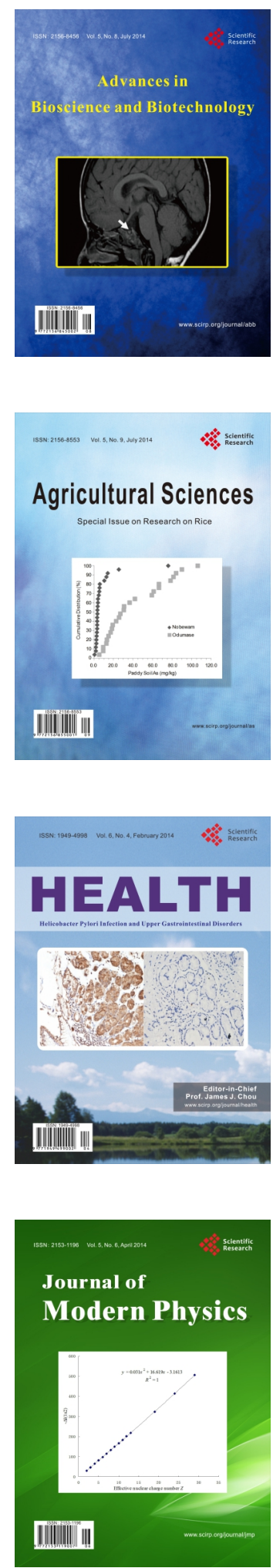
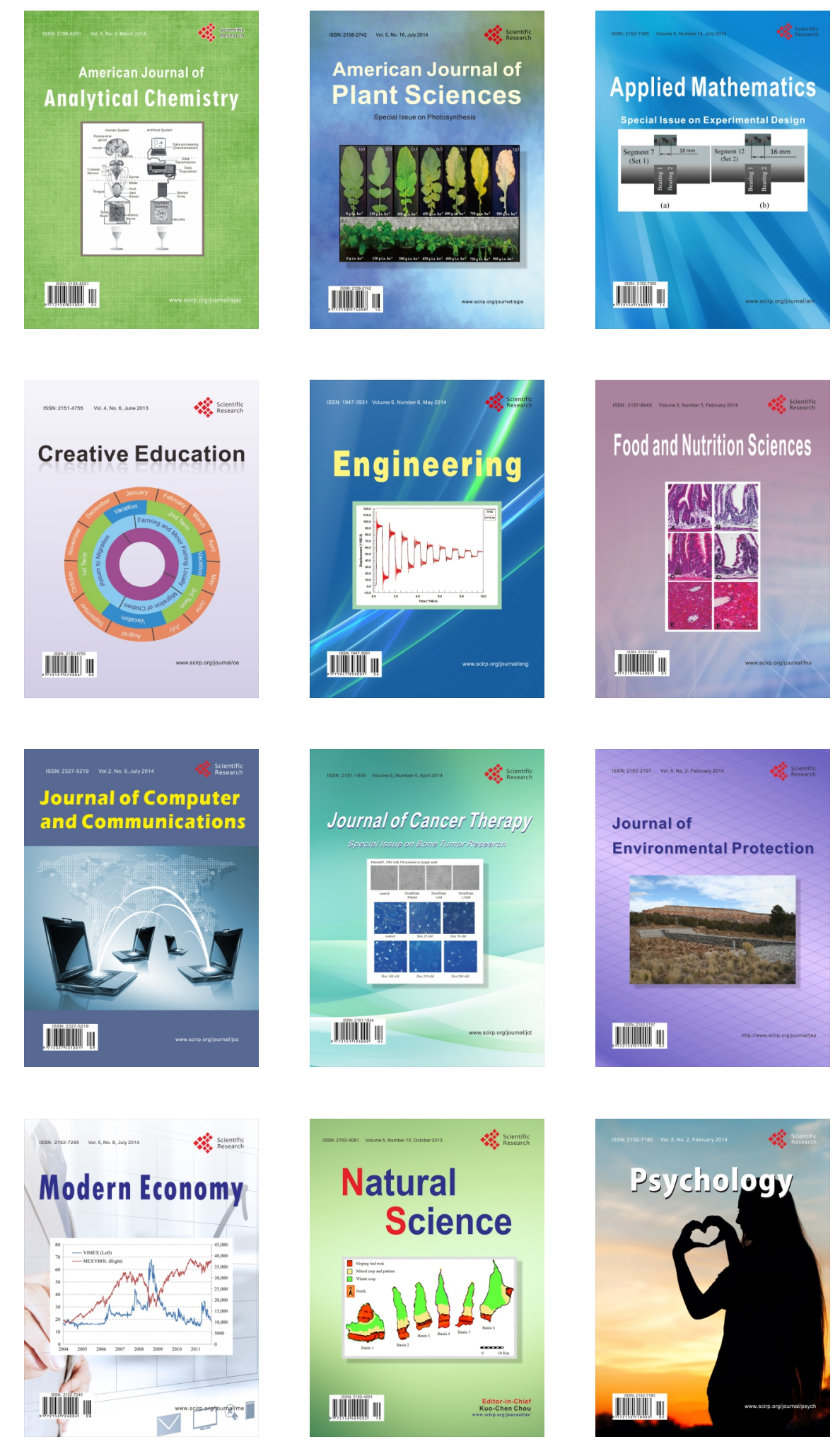